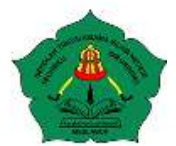

BASHA'IR

Jurnal Studi Alquran dan Tafsir

Published Desember 2021, 1(2): 75-84

P-ISSN: 2708-1018 | E-ISSN: 2708-100X

\title{
HUBUNGAN KARANTINA KESEHATAN DENGAN WABAH PENYAKIT MENURUT PENAFSIRAN ULAMA DALAM Q.S. 2:
}

\section{3}

\author{
Raisa Zuhra Salsabila Awaluddin ${ }^{1}$, Ahmad Murtaza MZ ${ }^{2}$ * \\ ${ }^{1}$ UIN Sumatera Utara ${ }^{2}$ UIN Sunan Kalijaga \\ Email: ${ }^{1}$ raisazuhra9@gmail.com \ ${ }^{2}$ ahmadmurtaza378@gmail.com
}

\begin{abstract}
Abstrak
Wabah yang menimpa manusia sangat mengerikan dan sangat mengganaskan. Masyarakat yang terdampak sebagai carrier dan yang terkena wabah sedikit yang mengkarantinakan dirinya saat terjadinya wabah penyakit. Terkait dengan hal tersebut Allah telah menjelaskan di dalam al-Qur'an berkenaan dengan itu. Para ulama tafsir dalam memahami hubungan karantina dengan wabah dapat dikaji agar dapat mendeskripsikan pandangan mufassir dalam memahami hubungan karantina dengan wabah penyakit, serta merelevansikan hubungan karantina dengan wabah di dalam al-Qur'an dan sains untuk mendapatkan pemahaman yang kuat di dalam al-Qur'an dan sains. Hubungan karantina kesehatan dengan wabah penyakit dilihat melalui 2 cara: pertama, melalui tafsir yang di dalam menceritakan tentang karantina dan wabah yang dapat menjadi ibrah dan yang kedua, melalui Asbab an-Nuzul Ayat yang di dalamnya terdapat iradah kawniyah yang dapat di pahami Allah memerintahkan kita untuk mengkarantinakan diri. Relevansi penafsiran hubungan karantina dan wabah dapat ditinjau dari tujuan karantina dan teknik karantina dan sejarah karantina, setelah melakukan observasi dan penyakit tersebar luas maka karantina dapat dilakukan dengan beberapa macam-macam karantina.
\end{abstract}

\begin{abstract}
The plague that afflicts humans is terrible and very vicious. Few people who are affected as carriers and who are affected by the outbreak quarantine themselves during the outbreak of the disease. In this regard, Allah has explained in the Qur'an regarding it. The scholars of interpretation in understanding the relationship between quarantine and epidemics can be studied to describe the view of commentators in understanding the relationship between quarantine and disease outbreaks, as well as the relevance of the relationship between quarantine and epidemics in the Qur'an and science to gain a strong understanding in the Qur'an. and science. The relationship between health quarantine and disease outbreaks can be seen in 2 ways: first, through an interpretation which tells about quarantine and epidemics that can become ibrah, and second, through Asbab an-
\end{abstract}


Nuzul Verse in which there is iradah kawniyah which can be understood by Allah commanding us. to self-quarantine. The relevance of the interpretation of the quarantine relationship and the epidemic can be viewed from the purpose of quarantine and quarantine techniques and quarantine history, after observing and spreading the disease, quarantine can be carried out with several types of quarantine.

Keywords: quarantine, plague, interpretation

\section{A. PENDAHULUAN}

Praktik karantina ditengah-tengah wabah bukanlah situasi baru yang dihadapi oleh manusia terkhusus umat Islam (Charismanto \& Rahmanto, 2021) Secara garis besar karantina adalah pergerakan/aktifitas seseorang yang menderita penyakit menular, walaupun belum adanya suatu gejala apapun, atau menyentuh alat angkut, yang diduga terkontaminasi oleh barang ataupun orang yang terdampak penyakit menular, hal ini termasuk ke mencegah penyebaran wabah penyakit. Adapun wabah penyakit adalah kejadian terjangkitnya penyakit menular di masyarakat yang jumlahnya meningkat dari jumlah biasanya pada waktu dan tempat tertentu serta menimbulkan banyaknya malapetaka.(Santoso, 2005) Menariknya, al-Qur'an sudah menjelaskan lebih dahulu tentang karantina dan wabah penyakit. Dalam hal ini Allah telah berfirman:

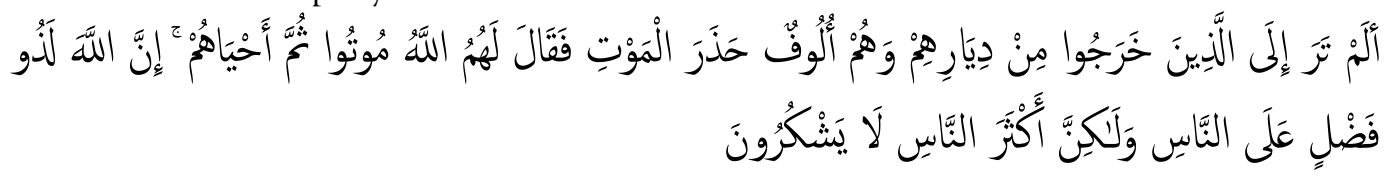

"Apakah kamu tidak memperhatikan orang-orang yang keluar dari kampong halaman mereka, sedang mereka beribu-ribu (jumlahnya) karena takut mati; maka Allah berfirman kepada mereka: 'Matilah kamu,' kemudian Allah menghidupkan mereka. Sesungguhnya Allah mempunyai karunia terhadap manusia tetapi kebanyakan manusia tidak bersyukur." (Qs. AlBaqarah:243).

Dalam Tafsir Nur al-Qur'an karya Kamal Faqih Imani menjelaskan sebab turunnya ayat ini adalah dahulu, Kota Suriah tertimpa penyakit wabah Pes yang menular dan menyebabkan kematian, karena itu banyak manusia yang meninggal pada saat itu. Oleh karena itu sebagian manusia meninggalkan kampung halaman nya (من ديار هم). Mereka tidak mau menjalankan kehendak Allah dan mengharapkan fenomena alam (wabah pes tersebut tidak tersebar) dapat menolong mereka. Mereka menjadi sombong, karena sebab itu Allah mematikan mereka di padang pasir tersebut dengan penyakit wabah pes itu karena mereka tidak mau menjalankan kehendak Allah.(Imani, 2006)

Dalam unggahan Nu Online, Kiyai Ma'ruf Khozin (Ketua Pimpinan Wilayah NU Center Jawa Timur) sudah tertulis di dalam al-Qur'an surah al-Baqarah ayat 243 tersebut mengenai wabah penyakit itu. Lebih lanjut dengan mengutip pendapat Ibnu Abbas, Ma'ruf Khozin mengatakan bahwa "mereka berjumlah 4.000 orang mereka keluar dari kampung mereka karena adanya wabah atau berusaha melarikan diri dari wabah, kita akan sampai di sebuah kampung yang tidak ada kematian di dalam nya. Sampai ketika mereka sampai di suatu tempat Allah berkata, matilah kalian 
(maksud kata disini karena mereka merasa sombong dan tidak menjalankan kehendak Allah) kemudian datanglah nabi, untuk menghidupkan mereka sehingga mereka bisa menyembahNya, maka Allah menghidupkan mereka. Dalam kisah tersebut mengandung pelajaran dan dalil yang menunjukkan bahwa tindakan menghindarkan diri dari takdir itu sama sekali tidak berguna. Dan bahwasanya tidak ada tempat berlindung dari ketentuan Allah Ta'ala kecuali kepadaNya. Karena mereka pergi dengan tujuan menghindarkan diri dari wabah penyakit untuk meraih kehidupan yang panjang, karena itu lah Allah berfirman matilah mereka. Kematian mendatangi mereka dengan cepat dan dalam satu waktu.(Setiawan, 2020) Dalam tafsir Ibnu Katsir, Thabari, Durr al-Mansur fi Tafir al-Matsur mereka memuatkan riwayat dari Ibnu Abbas, Ibnu Abbas memiliki sanad yang dekat dengan Rasulullah dan di dalam banyak tafsir mengemukakan tentang wabah penyakit dalam memahami ayat tersebut. Sebagaimana yang dicontohkan oleh Zamakhsyari dalam tafsirnya al-kasyaf mencantumkan dua hal terkait tafsiran yakni Menceritakan tentang wabah dan menceritakan tentang jihad fi sabilillah.(Zamakhsyari, n.d.)

Sejauh penelusuran penulis terkait penelitian sebelumnya yang membicarakan pandangan ahli tafsir terkait tafsiran Q.S. 2: 243 terdapat dalam sebuah penelitian yang dilakukan Fathur Rozaq terkait ibrah dari kisah konflik dari Bani Isra'il yang terdapat dalam Q.S. 2: 243-252 namun sayangnya tidak secara khusus menyinggung penafsiran tentang karantina yang terdapat dalam tafsiran ayat tersebut. (Rozaq, 2016) Maka dari itu, dari latar belakang di atas serta luputnya pembahasan atas penafsiran mengenai karantina yang terdapat dalam Q.S. 2: 243 masih luput dari penelitian, hingga menjadikan artikel ini menarik untuk diteliti lebih jauh lagi.

\section{B. METODE PENELITIAN}

Peneliti menggunakan jenis penelitian kepustakaan (Library Research), yang dengan ini menggunakan literatur dan kepustakaan, contohnya: buku-buku, artikel, jurnal, dan tulisan lain yang berkenaan dengan penelitian. Dengan menggunakan metode dokumentasi, maka dapat diperoleh data yang berkaitan dengan penelitian berdasarkan dari konsep kerangka penulisan yang telah di rancang sebelumnya. Sumber data primer adalah sumber data yang langsung memberikan data baik secara langsung maupun tidak langsung kepada pengumpul data, dalam hal ini peneliti banyak mengambil data dari kitab-kitab tafsir seperti tafsir Ibnu Katsir, tafsir jalalain, Tafsir Nur alQur'an, Mukhtashar Ibnu Katsir, dan buku beserta jurnal yang banyak membahas tentang penjelasan karantina dan wabah penyakit seperti Lessons from the History of Quarantine from Plague to Influenza A, Buku pintar sains dalam al-Qur'an.

Sumber data sekunder adalah sumber pendukung berupa teori yang peneliti dapat dari bukubuku, jurnal, dan juga karya-karya ilmiah lainnya serta literatur-literatur yang berkesinambungan dengan penelitian al-Qur'an yang berkaitan tentang hubungan wabah penyakit dengan karantina seperti, pandemi dalam al-Qur'an: Catatan Riset Dokter Hindia Belanda terdapat di dalam buku peraturan-peraturan untuk memelihara kesehatan dalam hukum syara' islam. The Canon Of medicine karya Ibnu Sina dalam ensiklopedia tersebut wabah bisa menyebar melalui partikel kecil yang tidak akan dapat dilihat dengan menggunakan mata telanjang.

Teknik pengumpulan data disini adalah dengan menggunakan dokumentasi berbagai sumber terkait penelitian hubungan karantina dengan wabah penyakit baik melalui data primer atau 
data sekunder dalam penelitian ini data primer adalah penafsiran Surah al-Baqarah ayat al-Qur'an 243. Dokumentasi berarti catatan peristiwa yang sudah berlalu yang berbentuk tulisan, atau karyakarya dan gambar yang berisikan suatu ide tertentu. (Sugiyono, 2008)

Teknik analisis data pada penelitian ini yang dipilih adalah deskriptif analistis, Berikut pengertian dari metode deskriptif analistis, deskriftif adalah pemaparan terhadap data yang sudah ada, dalam menganalisisnya tidak dibatasi pada pengumpulan data, tetapi juga termasuk dalam analisis dan penjelasan data tersebut. (Surakhmad, 1980) Analistis adalah memaparkan segala aspek di dalam penelitian dengan meneraangkan makna-makna yang termasuk ke dalam penelitian sesuai dengan data yang ingin diperoleh. (Baidan, 1998)

\section{HASIL DAN PEMBAHASAN}

1. Hubungan Karantina Kesehatan dengan Wabah Penyakit menurut surat Al-Baqarah ayat 243

\section{a. Hubungan Karantina Kesehatan dengan Wabah Penyakit menurut Penafsiran Ulama}

Pada ayat ini diceritakan kisah Bani Israil yang dahulu kala sebelum adanya Islam terjangkit sebuah wabah penyakit di kampung mereka. Penyeruan dan pengulangan ini sebagai pembelajaran dan bertujuan kepada yang belum pernah melihat dan belum juga mendengar. dan diserukan kepada Ahlul Kitab dan kepada sejarawan yang mendengar kisah mereka (Al-Baidhawi, 2011) Bani Israil tinggal di suatu perkampungan yang disebut (dawardan). Karena wabah tersebut, membuat Bani Israil yang menempati daerah itu merasa ketakutan. Mereka hendak menyelamatkan diri dari kematian dan menghindari diri dari wabah (tha'un) dan menghindar agar tidak terpapar wabah penyakit. Pendapat itu menurut Abdir Rahman Assulami mereka meninggalkan perkampungan itu dan lalu mereka turun ke lembah lalu Allah mematikan mereka. (Ahmad S. , 2016) Ibnu Abbas berkata jumlah mereka 4.000 dan ada juga yang berpendapat 8.000 dan dari Ibnu Wahab jumlah mereka 3.000 setengah, ada sebagian orang yang mengatakan 70.000 orang yang keluar dari tempat tinggal nya meninggalkannya dan melarikan diri dari wabah (tha'un). Mereka seraya berkata "kami menuju suatu tempat yang tidak ada kematian di dalamnya”. (Ahmad S. , 2016)

Mereka pergi berbondong-bondong meninggalkan tempat tinggalnya agar bisa memperpanjang kehidupannya. Karena jika terkena wabah penyakit itu mereka akan mati, karena di zaman dahulu tidak ada vaksin untuk terhindar dari penyakit itu. Mereka memilih pergi dari kampungnya agar mereka hidup yang lama di dunia. Di dalam Tafsir Jalalain Surah al-Baqarah ayat 243 ini mereka berpindah dan pergi dari tempat tinggalnya ke tempat yang lain di mana di sana tidak terdapat kematian akibat wabah (tha'un). Mereka membawa harta benda yang mereka miliki, mulai dari hewan dan lain sebagainya. Ketika mereka sampai di suatu lembah mereka kemudian menetap di lembah tersebut dan mereka meyakini wabah itu tidak akan sampai kepada mereka dan tempat itu adalah tempat yang aman. Kemudian Allah berfirman (موتو ا) Allah mematikan mereka beserta hewan yang dibawanya. Berbeda pendapat dalam menafsirkan kata ini ada yang mengatakan 8 hari ada juga yang mengatakan 7 hari mereka mati. Ibarat disini seperti 1 orang yang mati padahal jumlah mereka ribuan orang. (al-Mahalli \& Suyuti, 2008) Dan kejadian itu adalah kejadian diluar kebiasaan. Tentu semua itu karna kehendak Allah, Allah berfirman: 


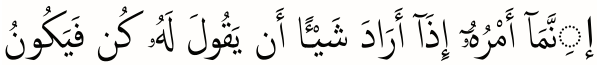

Sesungguhnya keadaan-Nya apabila Dia menghendaki sesuatu hanyalah berkata kepadanya: "Jadilah!" maka jadilah ia.

Sebab Allah mematikan mereka terdapat perbedaan pendapat ulama menanggapi hal ini alHasan berkata: Allah mematikan mereka sebab karena i'qab atas mereka kemudian Allah menghidupkan mereka kembali atas permintaan nabi dari nabi-nabi. Terdapat pendapat yang mengatakan, yang demikian itu adalah mukjizat kepada nabi yang bernama Nabi Sam'un. Nuqash berpendapat, mereka lari karena terkena demam. Ada pula yang mengatakan mereka lari dari jihad karena takut mati ketika Allah memerintahkan melalui lisan Nabi Hizqil. Mereka takut akan kematian dalam peperangan saat berjihad, lalu mereka lari dari kampung halaman nya. Allah mematikan mereka untuk memberitahukan bahwa mereka tidak akan selamat dari kematian kemudian Allah menghidupkan mereka lagi. Dalam pendapat ini yang paling cocok dalam penelitian ini adalah perkataan al-Hasan dan Nuqash dimana diceritakan sebagai I'qab dari mereka yang keluar dari rumah karena mereka sudah terkena gejala wabah yang ada di kampung mereka yaitu (demam).) (Ahmad A. M., 1995)

\section{b. Hubungan Karantina Kesehatan dengan Wabah Penyakit melalui Asbab an-Nuzul Ayat}

Melalui Asbab an-Nuzul Ayat terdapat penjelasan di dalam tafsir Nur al-Qur'an di jelaskan bahwa ketika masa itu ada wabah (thaun) di kota mereka (Bani Israil) yang menyebabkan mereka segerombolan manusia pergi dari kampung halamannya. Mereka berkata "daerah yang tidak akan mati kami akan pergi kesana” ribuan orang itu meninggalkan kotanya dan mereka percaya bahwa lari dari kampungnya adalah jalan terbaik untuk mereka agar terhindar dari kematian, tetapi mereka bukan lari dari kematian tapi menunjukkan kurangnya iman mereka. Pada saat itu kota Suriah tertimpa wabah pes atau sampar (plague) penyakit yang disebabkan oleh infeksi bakteri Yersinia Pestis, jika tergigit oleh serangga yang terdapat bakteri Yersinia Pestis bisa menghisap darah yang menyebabkan manusia meninggal. Pada saat itu juga beberapa manusia meninggalkan kampung halaman nya agar terhindar dari wabah tersebut dan akan hidup lama. mereka itu beribu-ribu orangnya (4000). Setelah terbebaskan oleh kematian mereka menjadi sombong, lalu mereka menolak kehendak Allah serta mengharapkan fenomena alam dapat membantu mereka lantas mereka lupa Allah lah yang maha segalanya, yang memberi kehidupan dan kematian.(Imani, 2006)

Kata kehendak Allah menurut pakar menyatakan ialah kehendaknya ada 2 macam, yang pertama: ketentuan yang tidak mengalami perubahan sehingga pasti terjadi. Itu disebut dengan iradah kawniyah dan yang kedua adalah iradah syar'iyah yang berkaitan dengan apa yang direstui Allah dan yang diperintahNya. Tetapi hal itu tidak pasti terjadi, kata itu berkaitan dengan usaha manusia dan kehendak manusia. Allah menghendaki kesehatan lahiriah dan batiniah bagi hamba-hambaNya dan juga memberikan petunjuknya untuk itu tetapi manusia harus bisa melangkah untuk meraih dan menghindari penyebab penyakit dan bencana. Seperti ajalnya manusia itu termasuk Iradah Syar'iyyah bagi siapa saja yang hidup. Jika sudah berusaha tetapi hasilnya tidak sesuai harapan maka kita terbentur dengan kehendak Allah yang bersifat kawniyah. (Shihab, 2020) Maka dari itu, dapat disimpulkan bahwa maksud dari kata "menolak kehendak Allah serta mengharapkan fenomena alam dapat membantu mereka" dapat dipahami bahwa kehendak atau perintah Allah disini adalah dengan menjaga diri untuk tidak keluar rumah ketika adanya wabah penyakit. 


\section{Relevansi Penafsiran Hubungan Karantina dengan Wabah dalam Al-Qur'an dan Sains}

Berikut penulis lampirkan terkait relevansi terkait penafsiran atas hubungan karantina dengan wabah dalam Al-Qur'an dan Sains dalam tinjauan sejarah karantina, tujuan karantina, teknik karantina, dan pelaksanaan karantina yang telah diterapkan di Indonesia.

a. Tujuan Karantina Kesehatan dalam kaitannya dengan Wabah Penyakit

Berikut penulis paparkan empat tujuan dari karantina terkait dengan wabah penyakit, yakni:

1. Agar terhindarnya masyarakat yang terinfeksi wabah penyakit.(WHO, 2021) Dengan melakukan karantina masyarakat akan terhindar dan tidak tertular penyakit yang terjadi di suatu tempat. Satu-satunya cara untuk lepas dari infeksi menghindari orang yang terinfeksi dan orang, barang, hewan yang terpapar. (Tognotti, 2013) Wabah penyakit itu tidak hanya dapat ditularkan kepada manusia melainkan melalui hewan-hewan, melalui barang-barang melalui tumbuhan bisa ditularkan dengan wabah penyakit. Hal ini sangat relevan dengan metode yang di terapkan dalam al-Qur'an bahwa karantina itu dapat menghindarkan diri dengan infeksinya wabah bukan lari dari kematian yang mereka fikirkan akan selamat dari kematian wabah penyakit.

2. Berkurangnya jumlah populasi yang terinveksi wabah penyakit menular dan mematikan. Dengan karantina tentu berkuranglah populasi orang yang terinveksi dengan menggunakan karantina sesuai wabah penyakit yang terkena/tertular.(Tim Kerja Kementerian Dalam Negeri, 2013) Hal itu sangat membantu bagi suatu negara dengan menutup jaringan ke luar negara atau kedalam, maka berkuranglah populasi yang terinveksi wabah penyakit. Dengan tertutupnya bisnis perdagangan dunia, perjalanan ke negara luar dan ke dalam.

3. Berkurangnya populasi yang mati karena adanya wabah. Dengan menggunakan metode karantina ini, maka berkuranglah populasi yang mati. Dengan menegaskan kepada masyarakat yang terkena atau yang terdampak carrier wabah untuk melakukan karantina.(UUD RI, 2018)

4. Hilangnya wabah dari permukaan. Dengan menggunakan metode karantina tentu hilanglah wabah dari permukaan. Walaupun pada dasarnya tidak 100\% hilang, hingga terciptanya lah vaksin bergantung kepada wabah yang di derita pada populasi tersebut. Dengan sedikitnya masyarakat yang tertular wabah penyakit maka lama kelamaan wabah itu akan hilang dari permukaan bumi.

\section{b. Teknik karantina dalam kaitannya dengan Wabah Penyakit}

Berikut penulis paparkan terkait teknik karantina yang berlaku yang penulis kutip dari Keputusan Menteri Kesehatan Republik Indonesia, yaitu:(Menteri Kesehatan Republik Indonesi, 2010)

- Isolasi Mandiri dapat dilakukan dengan cara mengasingkan diri dan barang-barang dari lingkungan masyarakat, mengasingkan ruangan dengan orang lain, menjaga jarak, melakukan observasi gejala.

- Karantina Rumah dilakukan setelah adanya epidemiologi yang diterapkan dalam pemerintahan daerah.

- Karantina Wilayah dapat dilakukan setelah adanya keputusan melalui Menteri Kesehatan berupa pernyataan telah terjadinya pandemi di wilayah tersebut dan mutasi 
hubungan karantina kesehatan dengan wabah penyakit menurut penafsiran ulama dalam q.s. 2: 243

genetik pada penyakit menular tertentu dan dapat menyebar luas antar manusia secara cepat dan juga mematikan.

- Karantina Rumah Sakit dilakukan setelah adanya perintah Menteri Kesehatan mengenai Karantina Rumah Sakit dan setelah mendapatkan laporan dari Direktur Rumah Sakit mengenai Pandemi di Rumah Sakit yang dapat meningkatkan kedaruratan kesehatan masyarakat di Rumah Sakit tersebut.

\section{c. Sejarah Karantina dan Wabah Penyakit}

Sebenarnya al-Qur'an sudah menjelaskan mengenai karantina dan ada juga hadist Rasulullah yang membicarakan tentang karantina dan wabah penyakit dan baru teruji oleh kedokteran pada zaman modern mengenai karantina itu sendiri.(Supriatna, 2020) Banyak penemuan penemuan yang teruji sekarang padahal adanya dalil mengenai hal itu yang disampaikan Allah ataupun Rasulullah, seperti sidik jari manusia, fenomena hujan darah, bahkan mengenai segala makhluk hidup diciptakan secara berpasangan, dan mengenai tanaman bertasbih. Sebelum karantina ini digunakan oleh para ahli medis di zaman modern, umat Islam telah mengenal metode karantina ini. Ibnu Sina, beliaulah ilmuwan muslim pertama yang mengenalkan metode karantina walaupun pada zaman dahulu sudah dijelaskan di dalam al-Qur'an dan hadist mengenai karantina. Ibnu sina membuat metode karantina untuk menghambat suatu wabah yang beliau tuliskan dalam karya monumentalnya "The Canon of Medicine". (Sahlah, 2015)

Ibnu Sina di kenal dengan nama Avicenna beliau berhasil menyumbangkan keahliannya di dalam bidang kesehatan hingga membuat buku tersebut menjadi rujukan wajib di dunia medis. Hingga beliau dijuluki dengan sebutan Bapak Kedokteran Dunia. Pada bukunya, Ibnu Sina juga menjelaskan tentang adanya infeksi atau kasus penyakit menular. (Sahlah, 2015) Menurut Ibnu Sina, suatu penyakit bisa diakibatkan oleh mikroorganisme tak terlihat oleh mata yang dapat menular pada lingkungan sekitarnya. Oleh karena itu mereka yang terinfeksi penyakit menular itu harus dikarantina untuk menghambat kasus penularannya. Metode karantina yang beliau temukan dengan sebutan al-Arba'iniya yang memiliki arti pembatasan ruang gerak manusia selama 40 hari. Pemikiran tersebut lalu dikenal dengan sebutan the fortieth / 40 hari, lalu diterjemahkan sebagai quarantena dalam Bahasa Venecian awal hingga menjadi kata karantina.(Nashrullah, 2018) Kala itu karantina harus dilakukan agar menghambat pertumbuhan dan mencegah penyakit kusta. Penyakit kusta adalah penyakit kulit berbahaya dengan sebuah infeksi yang ditandai dengan bercak putih pada kulit sehingga menjadikan penderita kehilangan anggota tubuhnya. Metode ini kemudian tersebar ke seluruh belahan dunia khususnya benua Eropa, terlebih lagi Ketika adanya wabah penyakit Black Death pada abad ke 14-15.(Nashrullah, 2018)

Setelah mengetahui relevansi penafsiran hubungan karantina dengan wabah dalam al-Qur'an dan Sains, penting untuk kita mengetahui macam-macam karantina di Indonesia.

\section{d. Macam-macam karantina di Indonesia}

\section{Isolasi Mandiri}

Merujuk pada Undang-Undang nomor 6 tahun 2018 tentang karantina kesehatan, isolasi mandiri memiliki tujuan untuk memantau kesehatan diri sendiri dan berusaha secara maksimal untuk menghindari terjangkitnya penularan penyakit. Berikut ini beberapa hal yang bisa dilakukan ketika sedang melakukan isolasi mandiri yaitu tidak berinteraksi secara langsung dengan orang lain, hindari berbagi barang pribadi dengan orang lain, menjaga kebersihan lingkungan sekitar, menggunakan ruangan terpisah dengan orang lain, menjaga jarak, melakukan observasi gejala, dan 
jika perlu hubungi tenaga medis apabila muncul gejala penyakit yang berkelanjutan.(Anggraini, 2020)

\section{Karantina Rumah}

Karantina Rumah dilakukan agar dapat menghambat penyebaran virus yang dilakukan dalam satu rumah. Hal ini dilakukan isolasi diri beserta benda-benda yang disinyalir dapat menularkan wabah penyakit. Dengan kata lain orang lain tidak dapat berinteraksi secara langsung dengan orang yang terduga terinfeksi wabah ataupun dengan benda yang telah digunakan. Sebab, wabah penyakit ini dapat hidup pada permukaan benda seperti logam, aluminium, kayu, kaca, dan plastik selama beberapa hari. Tetapi bergantung pada wabah yang terserang olehnya. Dalam kebutuhan untuk bersosialisasi tetap dapat dilakukan menggunakan internet melalui email atau telefon, telegram dll. Hindarilah berinteraksi sosial secara langsung apabila belum dinyatakan bebas dari wabah penyakit yang diderita pasien.

\section{Karantina Rumah Sakit}

Karantina ini memungkinkan adanya tindakan medis secara langsung dilakukan oleh tenaga medis di rumah sakit. Tindakan ini dilakukan untuk mengobati pasien yang terjangkit wabah penyakit sekaligus untuk mencegah penyebaran wabah penyakit pada orang lain di sekitar pasien agar wabah penyakit ini bisa teratasi. Saat ini, karantina rumah sakit merupakan hal yang wajib dipertimbangkan mengingat terjadinya ketimpangan/cacatnya kasus positif masyarakat yang terkena wabah penyakit dengan fasilitas medis yang ada. Maka diberlakukannya tindakan pencegahan diri untuk memutus mata rantai penyebaran wabah penyakit ini adalah tanggung jawab setiap individu di seluruh dunia.(Anggraini, 2020)

4. Karantina Fasilitas Khusus

Karantina Fasilitas Khusus dilakukan dengan fasilitas khusus yang hanya disediakan bagi orang yang terduga terinfeksi virus. Karantina ini hanya diberlakukan dengan pihak-pihak yang terkait. Jenis karantina fasilitas khusus ini merupakan langkah alternatif bagi Pemerintah jika fasilitas kesehatan tidak terpenuhi dan juga mampu menampung masyarakat yang memiliki gejala atas sakit itu serta riwayat kontak secara langsung dengan pasien yang positif terkena wabah penyakit. Alternatif ini dilakukan difasilitasi dan dikelola khusus untuk menangani wabah penyakit tersebut. Dapat dilakukan di tempat yang luas seperti wisma, hotel, asrama haji, ataupun tempat lain yang dirasa layak untuk menjadikannya rumah sakit darurat untuk menangani wabah pandemi virus terutama virus Covid-19 yang terjadi saat ini. Selain itu, fasilitas ini tetap harus diawasi kepada pihakpihak yang terkait dan berwenang di dalam bidangnya seperti Lembaga atau Kementerian, Pemerintah Daerah setempat antara lain Badan Penanggulangan Bencana Daerah (BPBD), TNI, Polri, Puskesmas, Dinas Kesehatan, Rumah Sakit, dan lain sebagainya. Fasilitas ini mendapatkan pembiayaan dan di bawah naungan langsung oleh Pemerintah di bawah naungan Kementerian, Gubernur, Walikota, ataupun Bupati yang memiliki wewenang urusan di wilayah fasilitas kesehatan darurat tersebut.(Anggraini, 2020)

\section{Karantina Wilayah}

Karantina jenis ini sering di sebut dengan lockdown. Sering kita dengar sekarang karena wabah penyakit Covid-19 yang banyak terjadi sekarang. Karantina wilayah dalam artian pemberhentian aktivitas suatu wilayah atau suatu negara karena terjadinya wabah penyakit. Karantina wilayah ini banyak dilakukan oleh negara negara besar khususnya di Eropa, dengan demikian jumlah wabah penyakit yang ada pada mereka turun secara drastis karena memang pemerintahannya menyediakan fasilitas. 
Saat virus wabah Covid-19, sekarang Indonesia menjadi negara yang populasinya meningkat keempat di dunia. Kebijakan mereka yang keliru membahayakan jutaan masyarakat di Indonesia. Sebagian negara lain melakukan penutupan migrasi, atau mengkarantinakan orang yang terdampak Covid-19, tetapi masyarakat Indonesia tidak melakukan hal seperti itu. Dari penjelasan di atas yang dilakukan masyarakat Indonesia ketika awal terkena wabah virus Covid 19 adalah dengan mengkarantinakan wilayah (lockdown), dan saat mengkarantinakan wilayah terjadi permasalahan ekonomi masyarakat yang menurun karena aktifitas di luar rumah yang berkurang. Maka dengan itu pemerintah mengambil kebijakan dengan Physical Distancing. Penanganan ini adalah penanganan yang bersifat ringan dari pada Lockdown dari tempat-tempat keramaian pada umumnya. Physical Distancing dapat mengurangi masyarakat yang terkena wabah penyakit maupun yang terdampak penyakit. Meskipun beberapa aktifitas di luar saat pandemi ini, namun tentu dengan terbatasinya jumlah populasi yang keluar dari rumah dan tetapnya menjaga Protokol Kesehatan dengan menggunakan masker saat terpapar dengan masyarakat lain. Hal ini untuk mencegah terjadinya wabah pada Indonesia.

\section{KESIMPULAN}

Hubungan karantina kesehatan dengan wabah penyakit menurut tafsir adalah di dalam ayat ini menceritakan tentang wabah penyakit yang terjadi di masa lalu yang berguna menjadi Ibrah untuk kita. Ketika itu Allah mematikan mereka yang berusaha lari dari kehendak Allah. Sebagaimana terdapat di dalam tafsir Nur al-Qur'an bahwa maksud kata kehendak pada ayat itu adalah iradah kawniyah yang bermaksud perintah Allah berarti maksud dari kalimat ini adalah perintah untuk tidak keluar dari rumah. Relevansi penafsiran hubungan karantina dengan wabah Penyakit ditinjau dari: Tujuan karantina agar tidak tertular, berkurangnya jumlah orang yang terinveksi wabah penyakit, berkurangnya jumlah orang yang mati, hilangnya wabah penyakit dari permukaan. Teknik karantina, terdapat di dalam Undang Undang tahun 2018 mengenai karantina kesehatan dengan melakukan Isolasi Mandiri, Karantina Rumah, Karantina Wilayah, Karantina Rumah Sakit. Sejarah karantina dan wabah yang juga menceritakan tentang perjalanan karantina di dalam dunia medis yang terjadi di zaman modern sekarang, sebenarnya al-Qur'an sudah menjelaskan tentang penerapan karantina dan di dalam hadist juga sudah menjelaskan penerapannya lebih lanjut, setelah itu penemuan Ibnu Sina yangmenjelaskan secara terperinci di dalam bukunya.

\section{DAFTAR PUSTAKA}

Ahmad, A. M. (1995). Al Jami' Lil Ahkam al-Qur'an (Vol. 3). Dar al-Kotob al-Ilmiyah: Dar al-Kotob al-Ilmiyah.

Ahmad, S. (2016). Mukhtashar tafsir Ibnu katsir (Vol. 1). Jakarta: Darus Sunnah Press.

Anggraini, M. (2020). Macam Karantina guna Mencegah Virus Crona Covid-19. Merdeka.Com.

Al-Baidhawi, N. (2011). Tafsir al-Qur'an (Vol. 1). Darul Kutub al-Ilmiyah.

al-Mahalli, \& Suyuti. (2008). Tafsir Jalalain (Vol. 1). PT. Sinar Baru Algesindo. 
Baidan, N. (1998). Metodologi Penafsiran Al-Qur'an. Yogyakarta: Pustaka Pelajar.

Charismanto, \& Rahmanto. (2021). Analisis Teologi Kesehatan Tentang Pandemi Virus Covid-19 Perspektif Al-Qur'an. Mashdar: Jurnal Studi Al-Qur'an Dan Hadis, 3(1), 167-188. Retrieved from https://ejournal.uinib.ac.id/jurnal/index.php/mashdar/article/view/2405

Nashrullah, N. (2018). Konsep Ibnu Sina dalam Hadapi Wabah dan Pembuktian Ilmiahnya. Republika.Co.Id.

Rozaq, F. (2016). Ibrah Kisah Konflik Bani Isra'il dalam Al-Qur'an (Telaah Penafsiran Ulama atas Ayat Konflik Bani Isra'il dalam Al-Qur'an Surat Al-Baqarah ayat 243-252). UIN Sunan Ampel. Surabaya: UIN Sunan Ampel.

Santoso, H. (2005). Tentang Wabah Penyakit Menular. In Badan Pembinaan Hukum Nasional Departemen Kehakiman dan Hak Asasi Manusia RI.

Setiawan, K. (2020). Tidak Keluar Rumah Saat Wabah Sesuai dengan Al-Qur'an. NU Online. https://www.nu.or.id/post/read/118109/tidak-keluar-rumah-saat-wabah-sesuai-dengan-al-quran

Sahlah, L. (2015). Peran Ibnu Sina Dalam Pengembangan Sains Islam di Persia (980-1037 M). UIN Syarif Hidayatullah, Adab Dan Humaniora. Jakarta: UIN Syarif Hidayatullah.

Shihab, Q. (2020). Corona Ujian Tuhan, Sikap Muslim Menghadapinya. Jakarta: Lentera Hati.

Sugiyono. (2008). Metode Penelitian Kuantitatif, Kualitatif dan REDD. Bandung: Alfabeta.

Supriatna, E. (2020). WABAH CORONA VIRUS DISEASE (COVID 19) DALAM PANDANGAN ISLAM. SALAM: Jurnal Sosial Dan Budaya Syar-I, 7(6), 561. Retrieved from https://doi.org/10.15408/sjsbs.v7i6.15247

Surakhmad, W. (1980). Pengantar PENELITIAN ILMIAH. Bandung: Tarsito.

Tognotti, E. (2013). Lessons from the History of Quarantine, from Plague to Influenza A. Emerging Infectious Diseases, 19(2), 254-259. Retrieved from https://doi.org/10.3201/eid1902.120312

Tim Kerja Kementerian Dalam Negeri. (2013). Pedoman Umum Menghadapi Pandemi Covid-19 Bagi Pemerintah Daerah : Pencegahan, Pengendalian, Diagnosis dan Manajemen. Journal of Chemical Information and Modeling, 53(9), 127. https://doi.org/10.1017/CBO9781107415324.004 